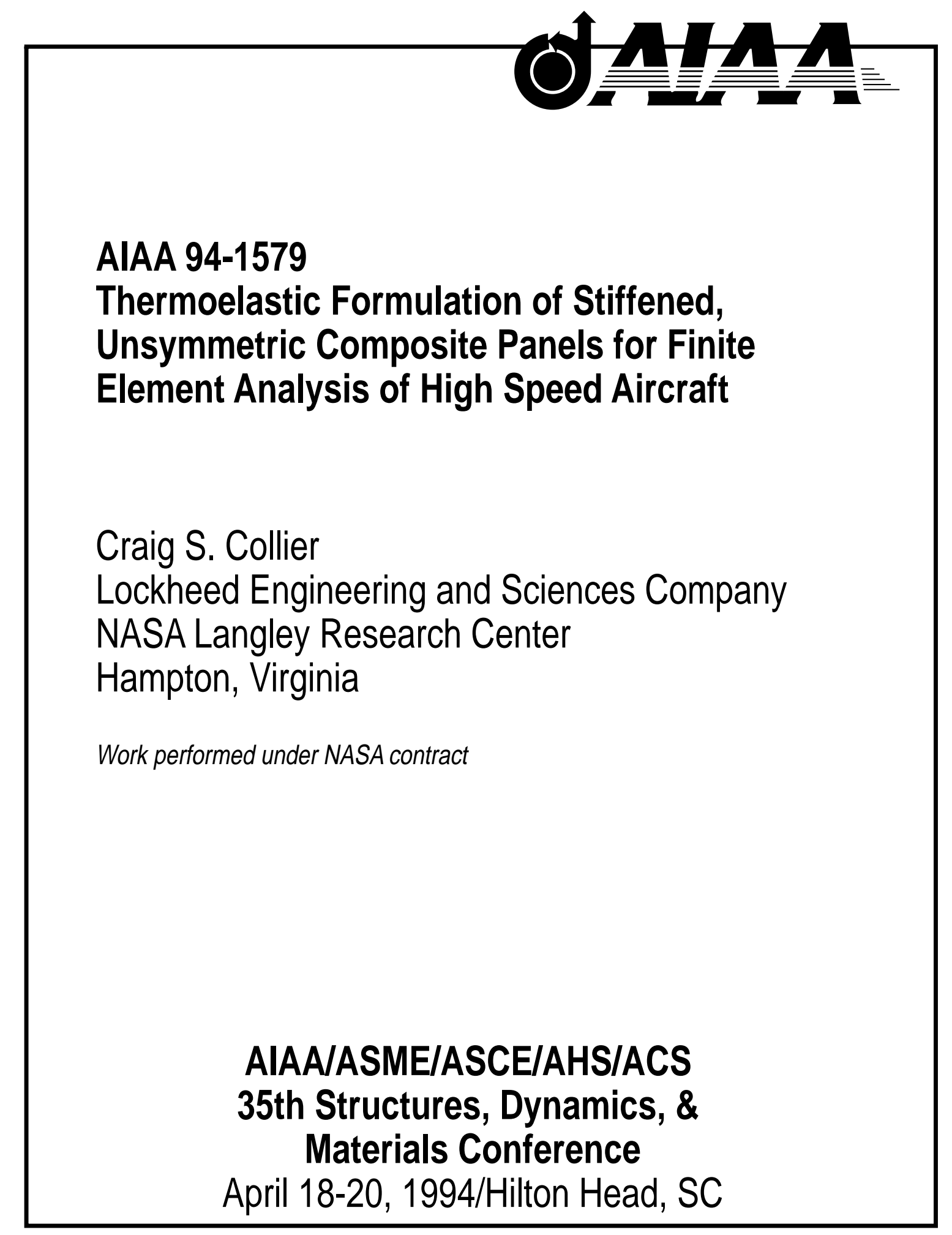

For permission to copy or republish, contact the American Institute of Aeronautics and Astronautics 370 L'Enfant Promenade, SW • Washington, D.C. 20024 


\title{
Thermoelastic Formulation of Stiffened, Unsymmetric Composite Panels for Finite Element Analysis of High Speed Aircraft
}

\author{
Craig S. Collier* \\ Principal Structures Engineer \\ Lockheed Engineering and Sciences Co. \\ NASA Langley Research Center \\ Hampton, VA
}

\begin{abstract}
An emerging technology need for capturing 3-D panel thermoelastic response with 2-D planar finite element models (FEMs) is aided with an equivalent plate stiffness and thermal coefficient formulation. The formulation is general and applies to all panel concepts. Included with the formulation is the ability to provide membrane-bending coupling of unsymmetric sections and calculation of all thermal expansion and bending responses from in-plane and through-the-thickness temperature gradients. Thermal residual strains for both the laminates and plies are included. The general formulation is defined and then applied to a hat-shaped, corrugated stiffened panel. Additional formulations are presented where required to include all of the hat's unique characteristics. Each formulation is validated independently with 3-D FEA.
\end{abstract}

\section{NOMENCLATURE}

\section{laminate or panel}

\begin{tabular}{|c|c|}
\hline $\begin{array}{l}\Delta \mathrm{T} \\
\Delta \mathrm{G}\end{array}$ & $\begin{array}{l}\text { In-plane temperature gradient } \\
\text { Through-the-thickness } \\
\text { temperature gradient }\end{array}$ \\
\hline$h_{i}$ & $\begin{array}{l}\qquad(i=1,2,3) \\
\text { Distance from the reference plane }\end{array}$ \\
\hline $\begin{array}{l}A_{i j}, B_{i j} \\
D_{i j}\end{array}$ & $\begin{array}{l}\text { Membrane, membrane-bending coupling, } \\
\text { and bending stiffness terms }\end{array}$ \\
\hline $\begin{array}{l}A_{i}^{\alpha}, B_{i}^{\alpha} \\
D_{i}^{\alpha}\end{array}$ & $\begin{array}{l}\text { Membrane, membrane-bending coupling, } \\
\text { and bending thermal force \& moment } \\
\text { coefficients }\end{array}$ \\
\hline & Reduced transformed laminate elasticities \\
\hline $\bar{\Phi}_{\mathrm{i}}^{*}$ & $\begin{array}{l}\text { Reduced transformed laminate thermal } \\
\text { force coefficients }\end{array}$ \\
\hline
\end{tabular}

\footnotetext{
* Senior member AIAA
}

This paper is a work of the U.S. Government and is not subject to copyright protection in the United States.

$$
(i=x, y, x y)
$$

$\mathrm{N}_{\mathrm{i}}, \mathrm{M}_{\mathrm{i}} \quad$ Reference plane forces and moments

$\varepsilon_{\mathrm{i}}, \kappa_{\mathrm{i}} \quad$ Reference plane strains and curvatures

$\begin{array}{cl}\text { superscripts } & \\ \mathrm{p} & \text { Panel } \\ \mathrm{T} & \text { Thermal } \\ \mathrm{M} & \text { Mechanical } \\ \mathrm{m} & \text { exponent value }\end{array}$

\section{INTRODUCTION}

Multidisciplinary conceptual design of high speed aircraft requires a quick structural analysis capability for vehicle optimization. High speed aircraft are often designed with stiffened and sandwich panels fabricated from fiberreinforced composite materials. The need for a quick analysis and the complexity of composite material, stiffened panels encourages approximations in the formulation of panel stiffness terms. The accuracy of approximate panel formulation is further diminished for hot environments caused by supersonic flight. Temperature gradients induce forces and moments which must be quantified with thermal expansion and bending coefficients. Formulation of thermal coefficients is also complex, so they too, are usually approximated.

This paper describes an equivalent plate stiffness and thermal coefficient formulation that applies to any panel concept, see Fig. 1. All stiffness and thermal coefficient data for membrane $[\mathrm{A}] \&\left\{\mathrm{~A}^{\alpha}\right\}$, bending $[\mathrm{D}] \&\left\{\mathrm{D}^{\alpha}\right\}$, and unsymmetric membrane-bending coupling $[\mathrm{B}] \&\left\{\mathrm{~B}^{\alpha}\right\}$ are captured for any stiffened shape. This paper examines the formulation's ability to analyze for the most general mechanical and thermal loading conditions by comparing its results with those produced by discrete, three dimensional FEA. The applicability of plate and beam analogies are addressed as well as the Kirchoff hypothesis, planesections-remain-plane. 


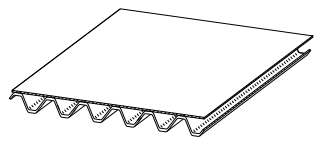

Corrugated-shaped, stiffened panel
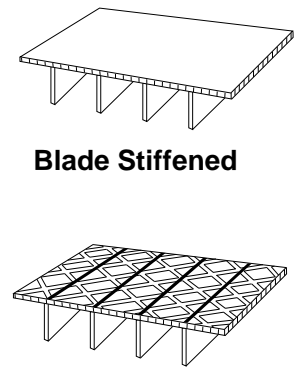

Waffle Grid

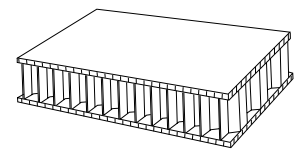

Honeycomb Sandwich
Blade Stiffened

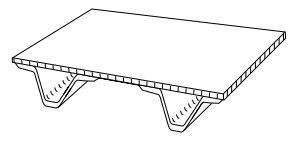

Hat Stiffened

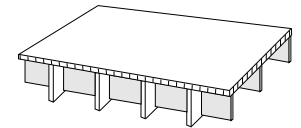

Bi-Axial Blade Stiffened

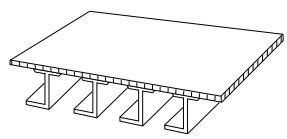

J Stiffened

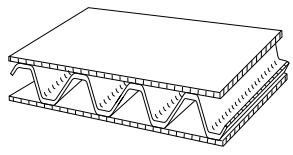

Trusscore Sandwich
Fig. 1 The formulation can be applied to any stiffened or sandwich, composite panel concept.

\section{Stiffened Panels}

Stiffened and sandwich panels efficiently provide buckling stability. They can carry more service load than unstiffened plates for a given unit weight. Stiffened panels are quite efficient for lightly loaded areas and applications of high temperature gradients. These qualities make them desirable for use as hot structure on high speed vehicles where weight reduction is a paramount objective.

Stiffened panels are unsymmetric, primarily by nature of their shapes as seen if Fig. 1. Unsymmetric stiffened shapes produce coupling even when the panel is fabricated with conventional isotropic materials. Sandwich panels become unsymmetric due to the effect of through-thethickness temperature gradients on their material elasticities. Quantification of unsymmetric behavior is important because it significantly alters panel response. Unsymmetric behavior causes coupling between membrane and bending panel response. Therefore, bending will either shorten or lengthen the panel midplane. Likewise, a change in panel length will create curvature. This membrane-bending coupling is quantified in classical lamination theory [1] with the [B] stiffness matrix. If change in panel shape and size is due to a change in temperature, then corresponding thermal coupling coefficients noted as $\left\{\mathrm{B}^{\alpha}\right\}$ must also be quantified.

A method for accurately including composite lamina and laminate data in the formulation of stiffened panel structural properties was first presented in reference 2 and later published in reference 3 . Thermal coefficients created to handle both in-plane and through-the-thickness temperature gradients for membrane, bending, and membranebending coupling were also introduced in reference 2 and then mathematically proven in reference 3 . Another paper, reference 4 showed how to input these data into the MSC/NASTRAN $^{\mathrm{TM}}$ finite element analysis (FEA) program [5] using a model with a single plane of finite elements. The significance of including them for an entire aircraft analyses is reported in reference 6 and 7 .

\section{Finite Element Analysis}

In-plane and through-the-thickness temperature gradients may be correctly applied and solutions obtained for anisotropic/orthotropic, unsymmetric, and unbalanced laminates or stiffened panels using a single plane of shell elements with the MSC/NASTRAN FEA program [3,4]. This is accomplished by including the full complement of smeared equivalent plate stiffness matrices and thermal expansion and bending coefficient vectors in the FEM.

Smeared equivalent plate stiffness and thermal coefficient formulations of this paper are particularly useful for coarsely meshed models of a complete structural entity such as an engine or airframe. Practical models of such large surface areas can only be accomplished with a single plane of shell finite elements. Too many elements are necessary to construct a discrete three-dimensional panel model over a complete airframe surface.

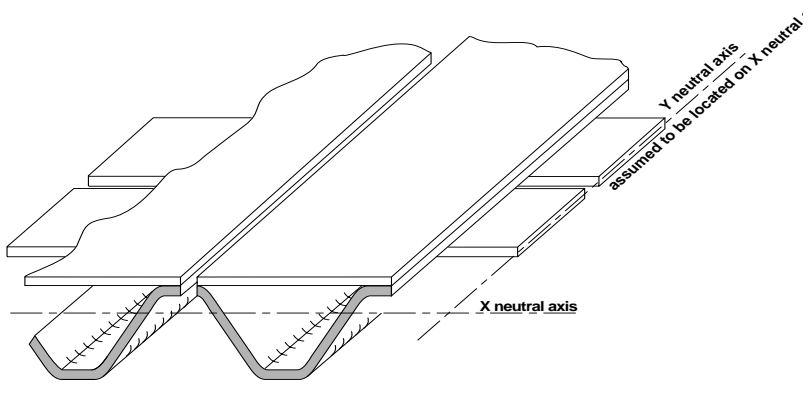

\section{Detached Wide Beam Analogy}

Missing:

- A12 \& D12 directional coupling terms

- $\left(1-v^{2}\right)$ plate poissons term

- Unsymmetric data

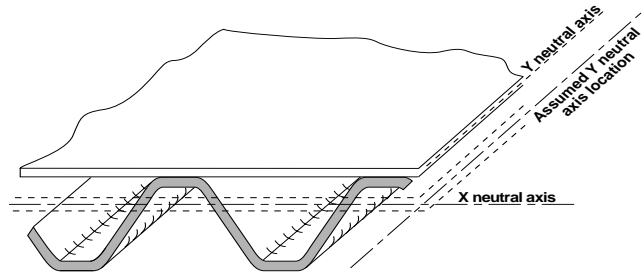

\section{Symmetric Panel Analogy \\ Missing: \\ - Unsymmetric membrane-bending coupling \\ stiffness terms and thermal coefficients}

Fig. 2 Traditional formulation of stiffened panels using beam and plate analogies. 


\section{STIFFENED PANEL EQUIVALENT PLATE FORMULATIONS}

\section{Traditional Formulation Described}

Fig. 2 summarizes two analogies for formulating stiffened panel properties. The most simplistic analogy is to represent the stiffened cross section as detached beams. The neutral axis for the $\mathrm{X}$-face is determined and the parallel-axis theorem is used to calculate bending stiffness on the $\mathrm{X}$-face. The same process is performed on the $\mathrm{Y}$ face. Coupling of forces and strains between the longitudinal and transverse directions is ignored by representing the panel as a series of separate beams. Therefore, the $A_{12}$, $D_{12}$ \& $\left(1-v^{2}\right)$ terms become omitted from the formulation.

A more advanced approach is to represent the stiffened panel using plate formulation, Fig 2. This analogy correctly includes longitudinal-transverse directional coupling, but is still in error by representing the $\mathrm{Y}$ neutral axis as lying on the same plane as the $\mathrm{X}$ neutral axis, thus, omitting the unsymmetric, membrane-bending coupling response of the panel.

\section{The New Formulation Described}

Description of the new panel formulation begins with a review of the previously reported laminate formulations. For a layered material, the membrane, membrane-bending coupling, and bending stiffnesses are noted as

$$
\left(A_{i j}, B_{i j}, D_{i j}\right)=\int_{-h / 2}^{h / 2}\left(\bar{Q}_{i j}\right)_{k}\left(1,-z, z^{2}\right) d z
$$

and reference 3 shows the corresponding thermal force and moment coefficients to be

$$
\left(\mathrm{A}_{\mathrm{i}}^{\alpha}, \mathrm{B}_{\mathrm{i}}^{\alpha}, \mathrm{D}_{\mathrm{i}}^{\alpha}\right)=\int_{-\mathrm{h} / 2}^{\mathrm{h} / 2}\left(\bar{\Phi}_{\mathrm{i}}\right)_{\mathrm{k}}\left(1,-\mathrm{z}, \mathrm{z}^{2}\right) \mathrm{dz}
$$

In equation (1) the

$$
\overline{\mathrm{Q}}_{\mathrm{ij}}=\mathrm{Q}_{\mathrm{ij}}\left[\mathrm{T}^{-4}\right.
$$

and are the transformed reduced layered elasticities of the laminae. $[\mathrm{T}]^{4}$ is a fourth order transfer tensor and $\mathrm{Q}_{\mathrm{ij}}$ are, as an example

$$
\mathrm{Q}_{11}=\frac{\mathrm{E}_{\mathrm{x}}}{\left(1-v_{21} v_{12}\right)}
$$

In equation (2) the

$$
\bar{\Phi}_{\mathrm{i}}=\mathrm{Q}_{\mathrm{ij}} \alpha_{\mathrm{i}}\left[\mathrm{T}^{-2}\right.
$$

and are the transformed reduced layered thermal force coefficients. $\alpha_{i}$ are the material expansion coefficients. This approach extended to panel concepts has been shown in references 2,3 , and 6 to be

$$
\left(A_{i j}^{p}, B_{i j}^{p}, D_{i j}^{p}\right)=\int_{-h / 2}^{h / 2}\left(\bar{Q}_{i j}\right)_{k}\left(1,-z, z^{2}\right) d z
$$

and

$$
\left(\mathrm{A}_{\mathrm{i}}^{\mathrm{p} x}, \mathrm{~B}_{\mathrm{i}}^{\mathrm{p} \alpha}, \mathrm{D}_{\mathrm{i}}^{\mathrm{p} \alpha}\right)=\int_{-\mathrm{h} / 2}^{\mathrm{h} / 2}\left(\bar{\Phi}_{\mathrm{i}}^{\star}\right)_{\mathrm{k}}\left(1,-\mathrm{z}, \mathrm{z}^{2}\right) \mathrm{dz}
$$

for the panel membrane, membrane-bending coupling, and bending stiffness terms and thermal coefficients. The asterisks indicate laminate and not lamina properties. The laminate properties are defined as

$$
\begin{aligned}
& \bar{Q}_{i j}^{\times}=\frac{A_{i j}}{t} \\
& \bar{\Phi}_{i}^{\times}=\frac{A_{i}^{\alpha}}{t}
\end{aligned}
$$

with material properties interpolated from a database, providing non-linear temperature and load dependent data based on the aircraft trajectory event. The FEA computed tension or compressive load and in-plane and through-thethickness temperature gradients are used to generate these laminate or metallic sheet properties. If the panel sheets are laminates, the properties of the sheet are treated as being homogeneous, which is a valid assumption because the panel depth is much greater than the laminate thicknesses $t_{1}, t_{2}$, or $t_{3}$. This assumption is also made in classical lamination theory because each ply is treated as being homogeneous even though it is a mixture of fiber and matrix.

The equivalent plate formulation of any stiffened panel shape, through extension of classical lamination theory, is accomplished by locating a reference plane, identifying its layers with a $k_{i}$ value, and defining the $h_{i}$ heights from the

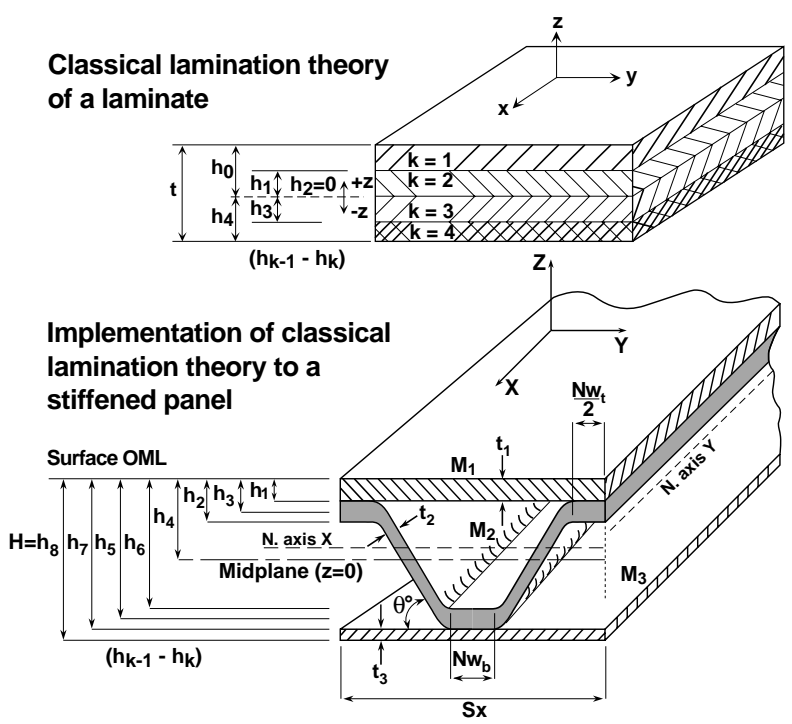

ILMNT FRMLTN(2)verticollie

Fig. 3 Laminate formulation is extended to stiffened panels. 
reference plane. The panel layers, in this sense, are the facesheet and coresheet laminates and joining nodes. This approach produces the following general equations for panel stiffness terms and thermal coefficients

$$
\begin{aligned}
\left(\mathrm{A}_{\mathrm{ij}}^{\mathrm{p}},-2 \mathrm{~B}_{\mathrm{ij}}^{\mathrm{p}}, 3 \mathrm{D}_{\mathrm{ij}}^{\mathrm{p}}\right) & =\sum_{\mathrm{k}=1}^{\eta} \frac{\left(\mathrm{h}_{\mathrm{k}-1}^{\mathrm{m}}-\mathrm{h}_{\mathrm{k}}^{\mathrm{m}}\right)}{\mathrm{S}}\left(\overline{\mathrm{Q}}_{\mathrm{ij}}^{\times}\right)_{\mathrm{k}} \\
& {\left[\mathrm{w}_{\mathrm{k}} \text { or } \frac{\mathrm{t}_{\mathrm{k}}}{\sin \theta}\right](\mathrm{m}=1, \mathrm{~m}=2, \mathrm{~m}=3) }
\end{aligned}
$$

$$
\begin{aligned}
\left(\mathrm{A}_{\mathrm{i}}^{\mathrm{p} \alpha},-2 \mathrm{~B}_{\mathrm{i}}^{\mathrm{p} \alpha}, 3 \mathrm{D}_{\mathrm{i}}^{\mathrm{p} \alpha}\right) & =\sum_{\mathrm{k}=1}^{\eta} \frac{\left(\mathrm{h}_{\mathrm{k}-1}^{\mathrm{m}}-\mathrm{h}_{\mathrm{k}}^{\mathrm{m}}\right)}{\mathrm{S}}\left(\bar{\Phi}_{\mathrm{i}}^{\times}\right)_{\mathrm{k}} \\
& {\left[\mathrm{w}_{\mathrm{k}} \text { or } \frac{\mathrm{t}_{\mathrm{k}}}{\sin \theta}\right](\mathrm{m}=1, \mathrm{~m}=2, \mathrm{~m}=3) }
\end{aligned}
$$

where $\mathrm{S}$ is the distance of the repeating pattern of corrugation and $\mathrm{w}$ is the width, $\mathrm{t}$ is the thickness, and $\theta$ is the angle of a stiffening segment $\left(\theta=90^{\circ}\right.$ for perpendicular stiffeners). Each stiffness term and thermal coefficient is the summation of all laminate/metallicsheet segments. If a segment is horizontal (in the plane of the panel) then its width is used. If a segment is vertical or at some angle, then its thickness divided by the sine of its angle is used. In this way, each segment and its shape can be accounted for in any panel concept.

In equations $(1,2,6,7,10$, and 11$)$ the $[B]$ and $\left\{B^{\alpha}\right\}$ are negative to match the sign convention of Fig. 3. These unsymmetric data are much more significant for stiffened panels than for laminates. A measure of the panel's membrane-bending coupling can be visualized in Fig. 2. The distance between the X-face and Y-face neutral axes can only be accommodated by the [B] and $\left\{\mathrm{B}^{\alpha}\right\}$ data. Since the $[\mathrm{B}]$ and $\left\{\mathrm{B}^{\alpha}\right\}$ data permit a common X-face and $\mathrm{Y}$-face reference plane, its location becomes a matter of choice. Conventional lamination theory uses the midplane, however, the vehicle outer mold line (OML) surface, or an offset to account for a thermal protection system, Fig. 4, would be a more convenient choice.

Kirchoff's plane-sections-remain-plane hypothesis Limitations and assumptions of the method as applied to any panel concept are the same as those applied in classical lamination theory. A primary assumption is that strain variation through the panel cross section follows the Kirchoff hypothesis for laminated plates. This hypothesis maintains that a normal to the midplane remains straight and normal upon panel deformation and that stresses in the XY plane govern the laminate

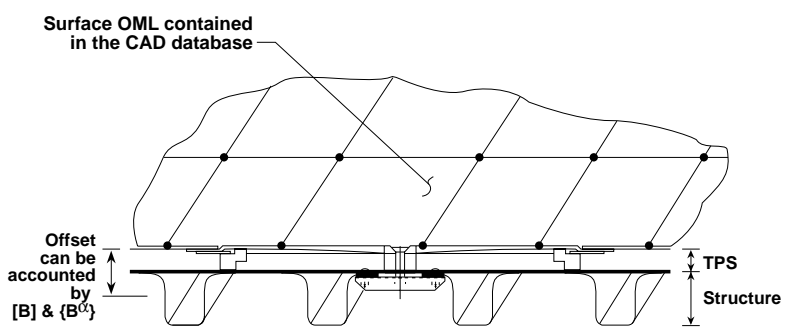

Fig. 4 Any reference plane may be used to calculate properties by including unsymmetric data.

behavior. Implications of this hypothesis are: 1) membrane strains vary linearly through the panel cross section 2) stresses vary in a discontinuous manner through the cross section 3) the facesheet laminates are perfectly bonded to the coresheets, and 4) the bonds are infinitesimally thin and non-shear deformable. This implies that $\varepsilon^{\mathrm{p}}, \gamma_{\mathrm{xz}}^{\mathrm{p}}, \& \gamma_{\mathrm{yz}}^{\mathrm{p}}=0$, in addition to the usual plane stress assumption of $\sigma^{\mathrm{p}}, \tau_{\mathrm{xz}}^{\mathrm{p}}, \& \tau_{\mathrm{yz}}^{\mathrm{p}}=0$.

3-D FEAs (hat shape modeled with shell elements) were performed for the purpose of investigating the strain profile of the stiffened panel. Strain and curvature for thermal expansion and bending, caused by both in-plane $(\Delta \mathrm{T})$ and through-the-thickness $(\Delta \mathrm{G})$ temperature gradients are shown in Fig. 5. As shown with the bold line, the free edge of the FEM indicates a linear strain distribution through the panel depth. FEA of general mechanical loads shows the same linear strain profile. However, some loadings can cause high shear strain gradients of the webs near the panel boundary if they are free (with out joining structure). Even for these special cases, the non-linear strain profile was seen to extend only a short distance from the free edge. Since stiffened panels do not have large deflections relative to their depths, they do not appear to have the same geometrically non-linear concerns of "thin" plates.

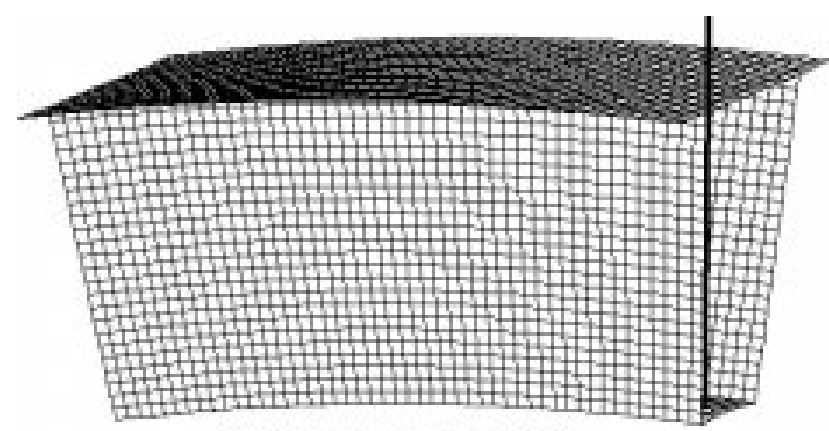

4896 elements $(75 x)$

Fig. 5 FEA computed thermal strain profile through the panel depth. 
Thermal load dependent residual strains and stresses Residual panel strains and stresses caused by thermal growth may be resolved in the same manner for varying stiffened shapes. They develop in stiffened panels, for each thermal loadcase, when the panel laminates elongate non-uniformly due to heating. The panel laminates cannot act independently and develop residual strains and stresses when forced to strain together as a unit of the panel. Panel curvature dictates that all laminate strains follow its through-the-depth strain profile. This profile is linear due to Kirchoff's hypothesis as discussed above. The residual strain is the difference between the strain that occurs in the laminate when made a segment of the stiffened panel's linear strain profile, and the strain that occurs in the laminate when allowed to thermally grow unattached to the panel.

2-D FEA is able to use smeared equivalent plate properties for a stiffened panel because of this "planesections-remain-plane" hypothesis. In principle, during 2D FEA, panel laminates strain together as a unit and thus do not include residuals. In order to quantify a laminate's "design-to" strains, its residual strains must also be quantified and added to 2-D FEA computed strains, see ref. 3. A comparison of residual stresses from discretely meshed, 3-D FEA and residual stresses computed with coarsely meshed 2-D FEA that includes the method of computing residuals is shown in Fig. 6 (back page)

\section{Formulations Specific to a Panel Concept}

The application of the general stiffness formulation to a specific panel concept is presented below. Though the formulation is general and applies to any panel concept, some panel concepts have particular behaviors which must be addressed in unique ways. Special stiffness terms are identified for each unique behavior of a corrugated stiffened panel and included in the general equations (10) and (11), where required.

The equations are grouped by panel direction in order to make them as brief as possible. $\mathrm{A}_{13}, \mathrm{~A}_{23}, \mathrm{~B}_{13}, \mathrm{~B}_{23}, \mathrm{D}_{13}$, and $\mathrm{D}_{23}$ are zero because the direction of corrugation is parallel to the panel's reference axis and because the laminates are balanced.

\section{$\mathrm{X}$-axis; stiffnesses parallel to the corrugation}

The longitudinal stiffness terms for a corrugated stiffened panel are

$$
\begin{aligned}
& \left(\mathrm{A}_{11}^{\mathrm{p}},-2 \mathrm{~B}_{11}^{\mathrm{p}}, 3 \mathrm{D}_{11}^{\mathrm{p}}\right)= \\
& {\left[\left(\overline{\mathrm{Q}}_{11}^{\times}\right)_{1}\left(\mathrm{~h}_{0}^{\mathrm{m}}-\mathrm{h}_{1}^{\mathrm{m}}\right)+\frac{\left(\overline{\mathrm{Q}}_{11}^{\times}\right)_{2^{\mathrm{t}}}\left(\mathrm{h}_{1}^{\mathrm{m}}-\mathrm{h}_{2}^{\mathrm{m}}\right) \mathrm{Nw}_{\mathrm{t}}}{\mathrm{S}_{\mathrm{x}}}+\right.} \\
& \frac{2\left(\overline{\mathrm{Q}}_{11}^{\times}\right)_{2}\left(\mathrm{~h}_{3}^{\mathrm{m}}-\mathrm{h}_{4}^{\mathrm{m}}\right) \mathrm{t}_{2}}{\sin \theta \mathrm{S}_{\mathrm{x}}}+\frac{2\left(\overline{\mathrm{Q}}_{11}^{\times}\right)_{2}\left(\mathrm{~h}_{4}^{\mathrm{m}}-\mathrm{h}_{5}^{\mathrm{m}}\right) \mathrm{t}_{2}}{\sin \theta \mathrm{S}_{\mathrm{x}}} \\
& \\
& \left.\frac{\left(\overline{\mathrm{Q}}_{11}^{\times}\right)_{2^{\mathrm{b}}}\left(\mathrm{h}_{6}^{\mathrm{m}}-\mathrm{h}_{7}^{\mathrm{m}}\right) \mathrm{Nw}_{\mathrm{b}}}{\mathrm{S}_{\mathrm{x}}}\right](\mathrm{m}=1, \mathrm{~m}=2, \mathrm{~m}=3)
\end{aligned}
$$

where geometric variables such as coresheet angle $\theta$, corrugation spacing $S_{x}$, and widths of the coresheet top and bottom joining nodes $\mathrm{Nw}_{\mathrm{t}}$ and $\mathrm{Nw}_{\mathrm{b}}$ are shown in Fig. 3. The laminate's $X$ axis is parallel to the panel's $X$ axis which is the corrugation direction. By using the OML surface as the panel's reference plane, the $h_{i}$ variables are calculated as: $\mathrm{h}_{0}=0, \mathrm{~h}_{1}=-\mathrm{t}_{1}, \mathrm{~h}_{2}=\mathrm{h}_{1}-\mathrm{Nt}_{\mathrm{t}}, \mathrm{h}_{3}=\mathrm{h}_{1}-\mathrm{Nt}_{\mathrm{t}} / 2, \mathrm{~h}_{4}=-\mathrm{H} / 2$, $\mathrm{h}_{8}=-\mathrm{H}, \quad \mathrm{h}_{7}=\mathrm{h}_{8}+\mathrm{t}_{3}, \quad \mathrm{~h}_{6}=\mathrm{h}_{7}+\mathrm{Nt}_{\mathrm{b}}, \quad$ and $\mathrm{h}_{5}=\mathrm{h}_{7}+\mathrm{Nt}_{\mathrm{b}} / 2$. The variables $t_{1}, t_{2}$, and $t_{3}$ are the top facesheet, coresheet, and bottom facesheet thicknesses. $\mathrm{Nt}_{\mathrm{t}}$ and $\mathrm{Nt}_{\mathrm{b}}$ are the thicknesses of the coresheet top and bottom joining nodes. Higher panel bending stiffnesses will be calculated if the OML is used but they will be balanced out with higher membrane-bending coupling stiffnesses. Note that a symmetric panel will now have non-zero membranebending coupling data. The advantages of using the OML instead of the panel neutral axis are explained in reference 3.

The subscripts 1,2 , and 3 on the $\overline{\mathrm{Q}}_{\mathrm{ij}}^{\times}$terms represent the different isotropic materials or composite layups. Properties of these materials or layups are based on their non-linear temperature and load dependent data. The terms $\left(\overline{\mathrm{Q}}_{\mathrm{ij}}^{\times}\right)_{2} \mathrm{t}$ and $\left(\overline{\mathrm{Q}}_{\mathrm{ij}}^{\times}\right)_{2} \mathrm{~b}$ distinguish the coresheet top and bottom node laminate reduced stiffnesses from the middle coresheet reduced stiffnesses. Even though they are the same material or layup, a through-the-thickness temperature gradient causes their properties to be dissimilar.

Unlike the facesheets, the corrugated coresheet does not behave as a plate. Its nodes and mid portion strain in the longitudinal direction like a thin strip of plate or a beam. Because of this, the coresheet does not contribute to the panel stiffness terms 22 and 12 of equations (15) and (17). More subtle is the fact that the coresheet's contribution to panel longitudinal stiffness as included in equation (12) is not effected by plate coupling as identified by equation (4). The coresheet's accordion shape allows it to strain unconfined in the transverse direction eliminating the need for the familiar plate term $\left(1-v^{2}\right)$. Coresheet laminate membrane stiffness $\left(\mathrm{A}_{11}\right)_{2}$ which includes orthotropic coupling cannot be divided by its thickness to obtain $\left(\overline{\mathrm{Q}}_{11}^{\star}\right)_{2}$ as shown in equation (8). Instead the coresheet's uncoupled $\left(\overline{\mathrm{Q}}_{11}^{-}\right)_{2}$ terms equal the effective laminate engineering elasticity, $\mathrm{E}_{\mathrm{x}}$

$$
\mathrm{E}_{\mathrm{x}}=\frac{\mathrm{A}_{11}\left(1-v_{\mathrm{xy}} v_{\mathrm{yx}}\right)}{\mathrm{t}}
$$

or more generally for unsymmetric or unbalanced laminates

$$
\mathrm{E}_{\mathrm{x}}=\frac{1}{\mathrm{~A}_{11}^{-1} \mathrm{t}}
$$


Y-axis; stiffnesses perpendicular to the corrugation The transverse stiffness terms for a corrugated stiffened panel are

$$
\begin{aligned}
& \left(\mathrm{A}_{22}^{\mathrm{p}},-2 \mathrm{~B}_{22}^{\mathrm{p}}, 3 \mathrm{D}_{22}^{\mathrm{p}}\right)= \\
& \quad\left[\left(\overline{\mathrm{Q}}_{22}^{\star}\right)_{1}\left(\mathrm{~h}_{0}^{\mathrm{m}}-\mathrm{h}_{1}^{\mathrm{m}}\right)+\frac{\left(\overline{\mathrm{Q}}_{22}^{\star}\right)_{2^{\mathrm{t}}}\left(\mathrm{h}_{1}^{\mathrm{m}}-\mathrm{h}_{2}^{\mathrm{m}}\right) \mathrm{Nw}_{\mathrm{t}}}{\mathrm{S}_{\mathrm{x}}}\right]
\end{aligned}
$$

$$
(\mathrm{m}=1, \mathrm{~m}=2, \mathrm{~m}=3)
$$

As noted in the longitudinal stiffness equations, the coresheet does not contribute to the transverse stiffness. However, if the coresheet top node is securely attached to the facesheet, as in the case when it is relatively wide and brazed to it, then its term shown in equation (15) is significant. If so, then its contribution to the longitudinal stiffness as shown in equation (12) is based on equation (8) and not equation (13) or (14). If the top coresheet node is spot welded to the facesheet then it should be omitted from equation (15). The transverse stiffness then becomes dependent on the fabrication method and must be properly considered with either 2-D or 3-D FEM's.

Curvature of the corrugated stiffened panel in the transverse direction causes coresheet flexure as noted in Fig. 7 As depicted, pure bending caused by an applied rotation on the end produces the same rotation at the facesheet and coresheet joint. This rotation causes the hat to take on the deflected shape shown, which is resisted by both coresheet and facesheet flexure. This additional $\mathrm{D}_{22}^{\mathrm{p}}$ bending stiffness can be quantified by taking ratios of the coresheet flexure stiffness to the facesheet flexure stiffness. With new shape variables $b$ and $b_{2}$, Fig. 8 , the additional stiffness term is

$$
\mathrm{D}_{22}^{\mathrm{p}^{\prime}}=\left(\frac{2\left(\mathrm{D}_{22}\right)_{2} \mathrm{~b}}{\left(\mathrm{D}_{22}\right)_{1} \mathrm{~b}_{2}}+\frac{\left(\mathrm{D}_{22}\right)_{2^{\mathrm{b}}} \mathrm{b}}{\left(\mathrm{D}_{22}\right)_{1} \mathrm{Nw}_{\mathrm{b}}}\right) \frac{\left(\mathrm{D}_{22}\right)_{1} \mathrm{~b}}{\left(\mathrm{~S}_{\mathrm{x}}\right)}
$$

which gives the panel over $180 \%$ more stiffness for the example panel shape shown later when the facesheet and coresheet are the same layup. In this equation, the laminate's bending stiffnesses are used instead of the $\overline{\mathrm{Q}}_{\mathrm{ij}}^{\times}\left(\mathrm{h}_{\mathrm{k}-1}^{\mathrm{m}}-\mathrm{h}_{\mathrm{k}}^{\mathrm{m}}\right)$ term to obtain more accuracy. The laminate's bending and membrane-bending stiffnesses could be used in equations (15) and (17) as well.

In summary, equation (15) is dependent on the choice of reference plane. It includes both parts of the parallel axis theorem which is the rotation and extension of the facesheet in the cross corrugation direction. Equation (16) is not effected by choice of reference plane, as it only quantifies the coresheet resistance to rotation.

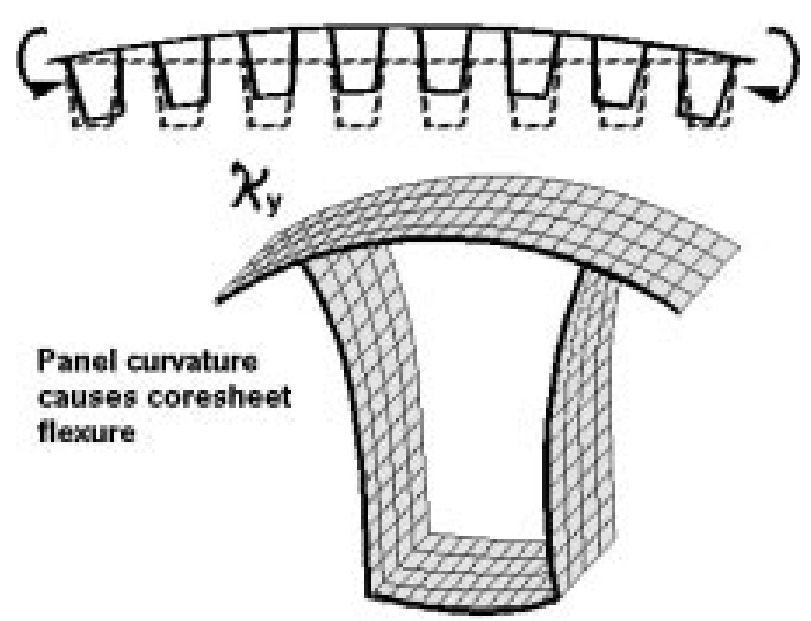

Fig. 7 Transverse panel bending is resisted by both the facesheet and coresheet.

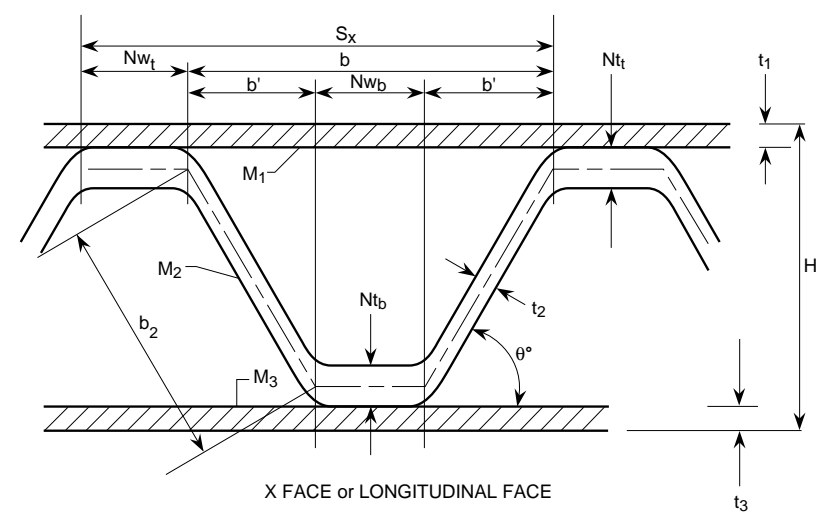

Fig. 8 Detailed shape variables are required for formulations.

XY-axis; directional coupling stiffnesses

The directional coupling stiffness terms for a corrugated stiffened panel are

$$
\begin{aligned}
& \left(\mathrm{A}_{12}^{\mathrm{p}},-2 \mathrm{~B}_{12}^{\mathrm{p}}, 3 \mathrm{D}_{12}^{\mathrm{p}}\right)= \\
& {\left[\left(\overline{\mathrm{Q}}_{12}^{\times}\right)_{1}\left(\mathrm{~h}_{0}^{\mathrm{m}}-\mathrm{h}_{1}^{\mathrm{m}}\right)+\frac{\left(\overline{\mathrm{Q}}_{12}^{\times}\right)_{2^{\mathrm{l}}}\left(\mathrm{h}_{1}^{\mathrm{m}}-\mathrm{h}_{2}^{\mathrm{m}}\right) \mathrm{Nw}_{\mathrm{t}}}{\mathrm{S}_{\mathrm{x}}}\right]} \\
& (\mathrm{m}=1, \mathrm{~m}=2, \mathrm{~m}=3)
\end{aligned}
$$

As noted in the transverse stiffness equations, if the coresheet top node is securely attached to the facesheet, then its term shown in equation (17) is significant. If the top coresheet node is not secure to the facesheet then it should be omitted from equation (17). 
XY-axis; in-plane shear, bending-twisting, and their coupling stiffnesses

The hat-shaped, closed cells of the corrugated stiffened panel behave like torque tubes. As such, they provide considerable additional stiffness to the panel $\mathrm{A}_{33}^{\mathrm{p}}, \mathrm{B}_{33}^{\mathrm{p}}$, $\mathrm{D}^{\mathrm{p}}{ }_{33}$ terms. These terms must be accurately formulated in order to take advantage of the unique characteristics of the corrugated panel. The $\mathrm{A}_{33}^{\mathrm{p}}$ and $\mathrm{D}_{33}^{\mathrm{p}}$ formulations are variations of those found in references 8 and 9 . The $\mathrm{B}_{33}^{\mathrm{p}}$ formulation is new. The $\mathrm{D}_{33}^{\mathrm{p}}$ formulation has been improved.

Formulation of these 33 terms is dependent on the way the panels will be joined together. A typical fuselage panel and ringframe assembly is shown in Fig. 9. This design fully attaches the panel facesheets to the ringframe with a splice plate and many fasteners. Therefore, the three translational and the three rotational facesheet boundary conditions are linked together. The coresheet is connected to the ringframe flange with a fastener as depicted in the cut away view. This attachment scheme allows the out-ofplane rotational degree-of-freedom of the bottom coresheet to be unconstrained, permitting limited hat cell warpage. Listed below are stiffness terms for this common design. Once the 33 terms have been calculated based on their application, they can be entered in the 2-D FEM without having to manually release this rotational degree-offreedom as required for a 3-D FEM. Fig. 10 shows the proper panel shear deformation and Fig. 11 the proper bending-twisting curvature, both with hat warping, as performed with 3-D FEA.

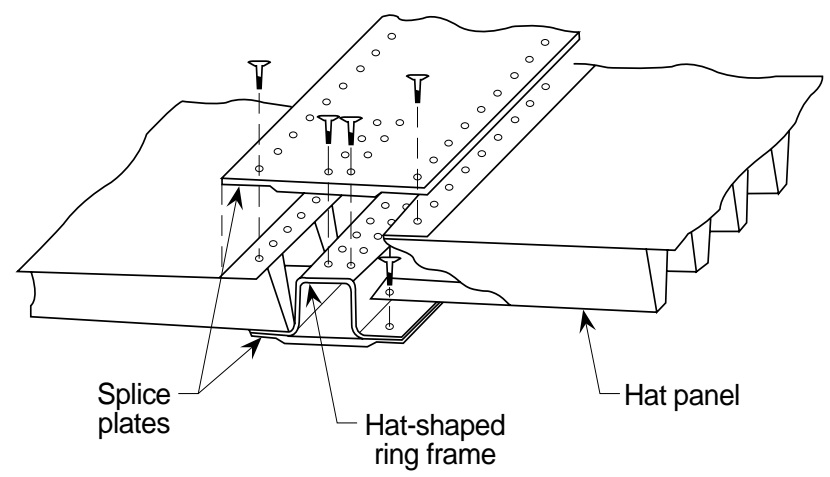

Fig. 9 A typical panel joint design assembly is used for formulations.

The in-plane shear stiffness term for a corrugated stiffened panel is

$$
A_{33}^{p}=\frac{S_{x}}{\frac{N w_{t}}{\left(A_{33}\right)_{4}}+\frac{2 b_{2} q_{c r}}{\left(A_{33}\right)_{2}}+\frac{N w_{b} q_{c r}}{\left(A_{33}\right)_{2}}}
$$

This equation is derived from the knowledge that a constant shear flow (q) exists around the hat-shaped, closed cell. Quantifying the ratio $\left(\mathrm{q}_{\mathrm{cr}}\right)$ of the cell shear flow, to the panel shear $\left(\mathrm{N}_{\mathrm{xy}}\right)$ aids the $\mathrm{A}_{33}$ formulation. Calculation of this ratio is indeterminate but can be solved by using the panel strain kinematics and the cell shape variables

$$
q_{\mathrm{cr}}=\frac{1}{1+\frac{\left(\mathrm{A}_{33}\right)_{1}}{\mathrm{~b}}\left[\frac{2 \mathrm{~b}_{2}}{\left(\mathrm{~A}_{33}\right)_{2}}+\frac{\mathrm{Nw}_{\mathrm{b}}}{\left(\mathrm{A}_{33}\right)_{2} \mathrm{~b}}\right]}
$$

where, for brevity, the following variables are used

$$
\begin{aligned}
& \left(\mathrm{A}_{33}\right)_{1}=\left(\overline{\mathrm{Q}}_{33}^{\circ}\right)_{1}\left(\mathrm{~h}_{0}-\mathrm{h}_{1}\right) \\
& \left(\mathrm{A}_{33}\right)_{2}=\left(\overline{\mathrm{Q}}_{33}^{\circ}\right)_{2} \mathrm{t}_{2} \\
& \left(\mathrm{~A}_{33}\right)_{2^{\mathrm{b}}}=\left(\overline{\mathrm{Q}}_{33}^{\circ}\right)_{2^{\mathrm{b}}}\left(\mathrm{h}_{6}-\mathrm{h}_{7}\right) \\
& \left(\mathrm{A}_{33}\right)_{2^{\mathrm{t}}}=\left(\overline{\mathrm{Q}}_{33}^{\circ}\right)_{2^{\mathrm{t}}}\left(\mathrm{h}_{1}-\mathrm{h}_{2}\right) \\
& \left(\mathrm{A}_{33}\right)_{4}=\left(\overline{\mathrm{Q}}_{33}^{\star}\right)_{1}\left(\mathrm{~h}_{0}-\mathrm{h}_{1}\right)+\left(\overline{\mathrm{Q}}_{33}^{\star}\right)_{2^{\mathrm{t}}}\left(\mathrm{h}_{1}-\mathrm{h}_{2}\right)
\end{aligned}
$$

and, from Fig. 8

$$
\begin{aligned}
\mathrm{b} & =\mathrm{S}_{\mathrm{x}}-\mathrm{Nw}_{\mathrm{t}} \\
\mathrm{b}_{2} & =\frac{\mathrm{h}_{3}-\mathrm{h}_{5}}{\sin \theta}
\end{aligned}
$$

Shear flow and laminate shears are

$$
\begin{aligned}
\mathrm{q} & =\mathrm{q}_{\mathrm{cr}} \mathrm{N}_{\mathrm{xy}}^{\mathrm{p}} \\
\mathrm{N}_{\mathrm{xy}}^{\mathrm{p}} & =\mathrm{N}_{\mathrm{xy}_{4}}=\mathrm{N}_{\mathrm{xy}_{1}}+\mathrm{q}
\end{aligned}
$$

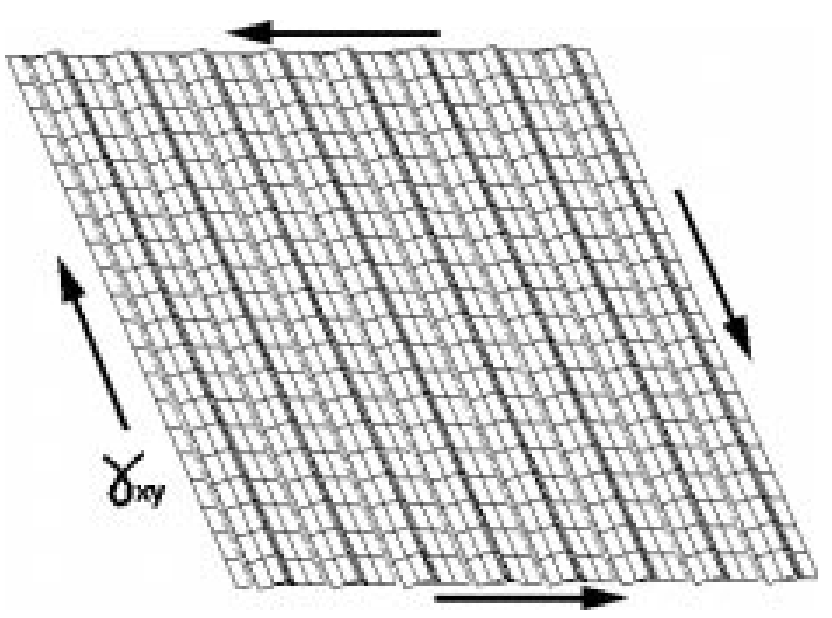

Fig. 10 Computed shear deformation of a 3-D FEM.

Shear flow around the cell causes coupling between inplane shear and bending-twisting. This response is 
included in $\mathrm{B}^{\mathrm{p}}{ }_{33}$. $\mathrm{B}^{\mathrm{p}}{ }_{33}$ has two parts: the first part noted as $B_{33}^{p}$ quantifies the twist caused from the cell shear flow, and the second part quantifies the panel twist from the in-plane shear of the facesheet as a function of the reference plane location

$$
\mathrm{B}_{33}^{\mathrm{p}}=-\frac{1}{2}\left[\left(\overline{\mathrm{Q}}_{33}^{\star}\right)_{1}\left(\mathrm{~h}_{0}^{2}-\mathrm{h}_{1}^{2}\right)+\frac{\left(\overline{\mathrm{Q}}_{33}^{\star}\right)_{2^{2}}\left(\mathrm{~h}_{1}^{2}-\mathrm{h}_{2}^{2}\right) \mathrm{Nw}_{\mathrm{t}}}{\mathrm{S}_{\mathrm{x}}}\right]+\mathrm{B}_{33}^{\mathrm{p}}
$$

where

$$
\mathrm{B}_{33}^{\mathrm{p}^{\prime}}=\mathrm{A} \mathrm{q}_{\mathrm{cr}} \frac{\mathrm{A}_{33}^{\mathrm{p}}}{\mathrm{S}_{\mathrm{x}}}
$$

and the cell area and height is

$$
\begin{aligned}
A & =\left(\frac{b+N w_{b}}{2}\right) H_{c e l l} \\
H_{c c l l} & =h_{0}-\frac{t_{1}}{2}-h_{5}
\end{aligned}
$$

The derivation of $\mathrm{B}_{33}^{\mathrm{p}}$ begins by noting that the cell shear flow causes torque in proportion to the area enclosed by the cell. The Bredt formula quantifies this as

$$
\mathrm{T}=2 \mathrm{Aq}
$$

The relation of torque to the bending-twisting moment is

$$
\mathrm{M}_{\mathrm{xy}}=\frac{\mathrm{T}}{2 \mathrm{~S}_{\mathrm{x}}}
$$

The cell shear flow can be written in terms of

$$
\mathrm{q}=\mathrm{q}_{\mathrm{cr}} \mathrm{A}_{33}^{\mathrm{p}}
$$

by knowing that

$$
\mathrm{N}_{\mathrm{xy}}^{\mathrm{p}}=\mathrm{A}_{33}^{\mathrm{p}} \gamma_{\mathrm{xy}}^{\mathrm{p}}
$$

and using equation (22). The coupling term due to shear flow can be written as

$$
\mathrm{B}_{33}^{\mathrm{p}^{\prime}}=\frac{\mathrm{M}_{\mathrm{xy}}^{\mathrm{p}^{\prime}}}{\gamma_{\mathrm{xy}}^{\mathrm{p}}}
$$

when all other strains and curvatures are zero. By substituting equations (26), (28), and (29) into equation (27), equation (30) becomes equation (24).

Applied moment $\mathrm{M}_{\mathrm{xy}}$ or torque is resisted by the panel's bending-twisting stiffness $\mathrm{D}^{\mathrm{p}}{ }_{33}$. The corrugated panel's closed cells provide much more rigidity than an open cross section such as the blade stiffened panel. The resulting differences are important because the $D_{33}$ term has four times the effect of increasing the panel's buckling load than does the primary bending stiffness $\mathrm{D}_{11}$.
$\mathrm{D}_{33}^{\mathrm{p}}$ also has two parts: the first part noted as $\mathrm{D}_{33}^{\mathrm{p}}$ quantifies the resistance to twist caused from the cell shear flow, and the second part quantifies the panel resistance to twist from the in-plane shear of the facesheet as a function of the reference plane location

$$
\mathrm{D}_{33}^{\mathrm{p}}=\frac{1}{3}\left[\left(\overline{\mathrm{Q}}_{33}^{*}\right)_{1}\left(\mathrm{~h}_{0}^{3}-\mathrm{h}_{1}^{3}\right)+\frac{\left(\overline{\mathrm{Q}}_{33}^{*}\right)_{2^{2}}\left(\mathrm{~h}_{1}^{3}-\mathrm{h}_{2}{ }^{3}\right) \mathrm{Nw}_{\mathrm{t}}}{\mathrm{S}_{\mathrm{x}}}\right]+\mathrm{D}_{33}^{\mathrm{p}}
$$

where

$$
\mathrm{D}_{33}^{\mathrm{p}}=\frac{\mathrm{A}^{2}}{\mathrm{~S}_{\mathrm{x}} \oint \frac{\mathrm{ds}}{\mathrm{A}_{33}}}
$$

is written in terms of $\mathrm{M}_{\mathrm{xy}}$ and $d s$ is the length of the cell perimeter. The $\mathrm{D}_{33}^{\mathrm{p}}$ formulation is a form of the familiar closed cell torsional rigidity equation. It is applicable to any closed shape and is independent of the reference plane location. Applied to the hat cell, equation (32) becomes

$$
\mathrm{D}_{33}^{\mathrm{p}^{\prime}}=\frac{\frac{\mathrm{A}^{2}}{\mathrm{~S}_{\mathrm{x}}}}{\mathrm{G}_{\mathrm{f}}+\frac{2 \mathrm{~b}_{2}}{\left(\mathrm{~A}_{33}\right)_{2}}+\frac{\mathrm{Nw}_{\mathrm{b}}}{\left(\mathrm{A}_{33}\right)_{2} \mathrm{~b}}}
$$

where $G_{f}$ accounts for the cell facesheet shear flexibility. $\quad G_{f}=b /\left(A_{33}\right)_{1}$ when the cell is not part of a panel and the entire cross section is allowed to warp. $G_{f}=0$ for the case where the cell is still not part of a panel, but the facesheet is prevented from warping, as in the design of Fig. 9. When the cell is part of a panel, the shear flexibility of the facesheet between cells allows shear flow into the cell facesheet even though the facesheet's average warpage and shear strain is prevented. Therefore, for the hat panel, $\mathrm{G}_{\mathrm{f}}=\mathrm{Nw}_{\mathrm{t}} / \mathrm{S}_{\mathrm{x}}\left(\mathrm{A}_{33}\right)_{4}$

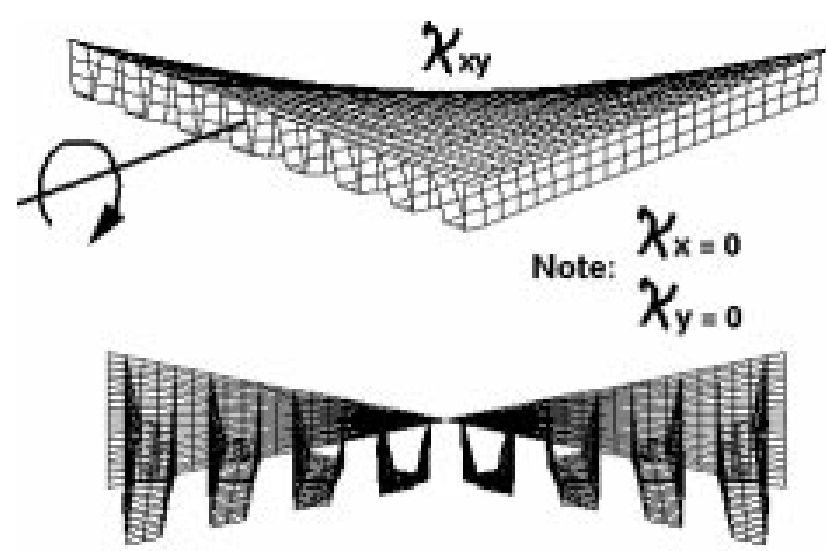

Fig. 11 Computed bending-twisting curvature of a 3-D FEM. 


\section{STIFFENED PANEL EQUIVALENT PLATE VERIFICATION}

\section{Twelve unique stiffness terms}

An anisotropic panel has eighteen unique stiffness terms. The 13 and 23 terms of the [A], [B], and [D] matrices become zero leaving twelve unique terms for a corrugated panel that is fabricated with balanced layups and is modeled with the panel's axis parallel or perpendicular to the corrugation. Values for these twelve unique stiffness terms were calculated using the formulations of this paper and then compared to 3-D FEA. Two reference planes were used to test the generality of the equations. Table 1 lists values for the panel midplane and Table 2 lists values for the facesheet midplane. The facesheet midplane is a useful reference plane because it is close to the OML surface and because it is the location where the smallest values for $\mathrm{B}_{12}^{\mathrm{p}}, \mathrm{B}_{22}{ }_{22} \mathrm{D}^{\mathrm{p}}{ }_{12}$, and $\mathrm{D}^{\mathrm{p}}{ }_{22}$ occur.

The twelve stiffness terms were determined independently of each other by applying one known strain or curvature and setting all others to zero. By isolating each panel response this way, the six equations and six unknowns that relate panel strain and curvature to load

$$
\left\{\begin{array}{c}
N_{i} \\
M_{i}
\end{array}\right\}_{6 \times 1}=\left[\begin{array}{cc}
A_{i j} & B_{i j} \\
B_{i j} & D_{i j}
\end{array}\right]_{6 \times 6}\left\{\begin{array}{c}
\epsilon_{i} \\
\kappa_{i}
\end{array}\right\}_{6 \times 1}
$$

were used for measuring each stiffness term with 3-D FEA.

Six cases per reference plane (three unit strains and three unit curvatures) were applied to two different 3-D FEMs: a large panel area with many hats and a small panel area with many elements to represent the hat shape. Unit strains and curvatures were applied with MSC/NASTRAN $^{\mathrm{TM}}$ RBE2 rigid elements on each side of the panel. Unit enforced displacements or rotations were applied one at a time, maintaining all other deformations to be zero. The resulting reacted forces and moments were then used to measure any applicable terms. For instance, for a unit $\varepsilon_{\mathrm{x}}$, four terms can be measured

$$
A_{11}=N_{x}, \quad A_{12}=N_{y}, \quad B_{11}=M_{x}, \quad B_{12}=M_{y}
$$

The 3-D FEMs used for these comparisons had an inherent shortcoming of having the shell elements of the top coresheet co-planar to the facesheet elements. Coplanar elements were necessary to maintain connectivity to the same grid points. In lieu of off-setting the top coresheet properties in the FEM, the $h_{i}$ distances shown in Fig. 3 were adjusted for these comparisons. Also, for these comparisons, the stiffness terms were calculated assuming the panel was fabricated in a way that did not provide secure enough attachment between the top coresheet and facesheet to allow the transverse properties of the top coresheet to be used in any terms.
Panel Design and Temperatures

The panel cross section shape, dimensions, and laminate layups used for the stiffness term comparisons is shown in Fig. 12. To the left of the section is a temperature profile which is typical of those analyzed for hypersonic flight. The shaded rectangle represents a uniform in-plane gradient of $555^{\circ} \mathrm{F}\left(625^{\circ} \mathrm{F}-70^{\circ} \mathrm{F}\right)$. The double shaded triangles represent a through-the-thickness gradient of $300^{\circ} \mathrm{F} / \mathrm{in}$. By superimposing the two gradients, the variation of temperature through the panel's depth is known, as illustrated with the bold line. The facesheet's average temperature of $842.5^{\circ} \mathrm{F}$. and the coresheet's average temperatures of $832.75^{\circ} \mathrm{F}$., $617.5^{\circ} \mathrm{F}$, and $402.25^{\circ} \mathrm{F}$. were used for interpolating the material database. Temperature dependent laminate data $\bar{Q}_{i j}{ }_{i j}$ and $\bar{\Phi}_{i}^{\star}$ were used for formulating panel stiffness terms and thermal coefficients, in order to make the comparisons more challenging. The temperature gradients were not applied,as loads, because their induced thermal forces would have made the solutions indeterminate.

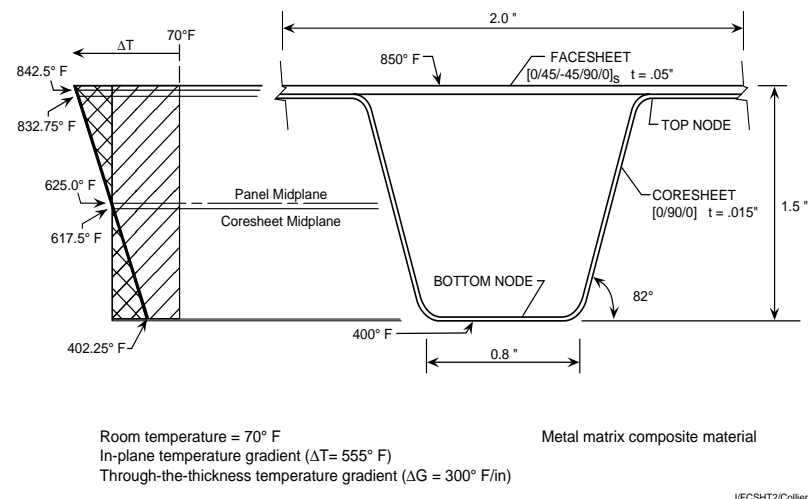

Fig. 12 The corrugated stiffened panel and temperature profile used for analysis.

\section{Observations}

Panel in-plane shear, bending-twisting, and their couplings are highly dependent upon boundary conditions, thus, equivalent plate formulations and 3D FEMs must be tailored appropriately. The $\mathrm{A}_{33}^{\mathrm{p}}, \mathrm{B}_{33}{ }_{33}$, and $\mathrm{D}^{\mathrm{p}}{ }_{33}$ are greatly increased by attaching the hats to a stiff support such as a ringframe. The $\mathrm{A}_{33}^{\mathrm{p}}, \mathrm{B}_{33}^{\mathrm{p}}$, and $\mathrm{D}^{\mathrm{p}}$ formulated values based on the design in Fig. 9 matched within $0.1 \%$ of FEA performed with the finely meshed model. The remaining nine stiffness terms were computed only with the larger, coarser meshed 3D FEM. They too compared well with formulated values (within 1\%) and are listed in tables (1) and (2). In short, all twelve stiffness terms are correctly formulated for the hat-shaped, corrugated stiffened panel.

The close comparisons to measured values indicate that this particular equivalent plate approach provides the capability to match 3-D FEA computed response for any general thermomechanical load condition. Implication of this match is that proper equivalent plate formulations of stiffness and thermal coefficients provide the capability to 
quantify the thermoelastic response of aircraft using relatively coarse meshed $2-\mathrm{D}$ models.

Regardless of choice of reference plane, the same correct solution of laminate strains and stresses are obtainable, even though the calculated stiffnesses and thermal coefficients, and computed moments vary greatly. Reference plane dependent, FEA computed thermomechanical $\mathrm{N}^{\mathrm{p}}$ and $\mathrm{M}^{\mathrm{p}}{ }_{\mathrm{i}}$ are multiplied by the $6 \times 6$ inverted stiffness matrix, see equation (34), to resolve reference plane $\varepsilon^{\mathrm{p}}{ }_{i}$ and $\kappa^{\mathrm{p}}{ }_{i}$. These panel reference plane $\varepsilon^{\mathrm{p}}{ }_{i}$ and $\kappa^{\mathrm{p}}{ }_{i}$ are then used in equation (36) to quantify strains at any location in the panel depth. A laminate strain is the summation of the panel's reference plane strain and the additive or subtractive contribution of the curvature

$$
\left\{\epsilon_{\mathrm{i}}\right\}_{\mathrm{k}}=\epsilon_{\mathrm{i}}^{\mathrm{p}}-\kappa_{\mathrm{i}}^{\mathrm{p}} \mathrm{H}_{\mathrm{k}}
$$

where $\mathrm{H}_{\mathrm{k}}$ is the distance between the reference plane and the panel depth location $\mathrm{k}$.

\section{CONCLUSIONS}

Formulations presented in this paper provide the capability to model stiffened composite panels of any cross sectional shape with a single plane of shell finite elements. Twelve unique stiffness terms were formulated for a corrugated, hat-shaped composite stiffened panel by extending classical lamination theory to the stiffened cross section, and by including the unique characteristics of the closed cells. A new formulation for the bending-twisting coupling with in-plane shear stiffness term $\left(\mathrm{B}^{\mathrm{p}}{ }_{33}\right)$ was derived and an improved $\mathrm{D}_{33}$ was presented. The formulated values were compared with 3-D FEA. All terms had differences less than $1 \%$. Implication of this agreement is that the equivalent plate formulations of stiffness and thermal coefficients presented in this paper provide the capability to quantify the thermoelastic response of aircraft using relatively coarse meshed 2-D models.

\section{ACKNOWLEDGEMENTS}

This work was performed for the National Aero-Space Plane Office/Systems Analysis Office under NASA contract NAS1-19000 at Langley Research Center in Hampton, Virginia.

\section{REFERENCES}

1 Jones,R.M., Mechanics of Composite Materials, Hemisphere Publishing Corporation, Washington, DC, 1975

2 Collier, C.S., COMPOSITE STIFFENED PANELS:

Part 1 - Stiffness, Thermal Expansion, and Thermal Bending Formulation for Finite Element Analysis, April 1992, NASP CR 1134
3 Collier, C.S., "Stiffness, Thermal Expansion, and Thermal Bending Formulation of Stiffened, FiberReinforced Composite Panels", AIAA/ASME/ASCE/ AHS/ASC 34th Structures, Dynamics, \& Materials Conference, La Jolla, CA, April 19-22, 1993, Paper No. AIAA-93-1569

4 Collier, C.S., Spoth,K.A., and Grassi,G.C., "Thermomechanical Finite Element Analysis of Stiffened, Unsymmetric Composite Panels With Two Dimensional Models", The MSC World Users' Conference, Arlington, VA, May 24-28, 1993, Paper No. 31

5 The MacNeal-Schwendler Corporation, $M S C /-$ NASTRAN User's Manual, Vol 1, Version 67, The MacNeal-Schwendler Corporation, Los Angeles, CA, Aug. 1991

6 Collier, C.S., "Structural Analysis and Sizing of Stiffened, Metal Matrix Composite Panels for Hypersonic Vehicles", AIAA 4th International Aerospace Planes Conference, Orlando, FL, December 1-4, 1992, Paper No. AIAA-92-5015

7 Collier, C.S., "Thermoelastic Analysis of Aero-Space Planes", Proceedings of the National Aero-Space Plane Technology Review, Monterey, CA, April 13-16, 1993, paper No. 100

8 Stroud, J.W., Elastic Constants for Bending and Twisting of Corrugation-Stiffened Panels, Dec. 1963, NASA TR R-166

9 Stoud,J.W. and Anderson,M.S., PASCO: Structural Panel Analysis and Sizing Code, Capability and Analytical Foundations, NASA TM 80181, Nov. 1981

\section{TRADEMARKS}

NASTRAN ${ }^{\mathrm{TM}}$ is a registered trademark of NASA MSC/NASTRAN ${ }^{\text {TM }}$ is an cnhanced proprictary product of the MacNeal-Schwendlcr Corporation 
Table 1. Comparisons of formulated stiffnesses to 3D FEA computed stiffnesses.

(the reference plane is the panel midplane)

\begin{tabular}{|c|c|c|c|c|c|c|c|c|c|c|c|c|}
\hline CASE & $A_{11}$ & $A_{12}$ & $\mathrm{~A}_{22}$ & $\mathrm{~A}_{33}$ & $\mathrm{~B}_{11}$ & $\mathrm{~B}_{12}$ & $\mathrm{~B}_{22}$ & $\mathrm{~B}_{33}$ & $\mathrm{D}_{11}$ & $\mathrm{D}_{12}$ & $\mathrm{D}_{22}$ & $\mathrm{D}_{33}$ \\
\hline $\begin{array}{l}\text { FORMU- } \\
\text { LATED }\end{array}$ & $\begin{array}{r}\mathbf{1 4 . 1} \\
(+05)\end{array}$ & $\begin{array}{r}\mathbf{2 . 6 0} \\
(+05)\end{array}$ & $\begin{array}{r}\mathbf{6 . 9 7} \\
(+05)\end{array}$ & $\begin{array}{r}\mathbf{2 . 1 2} \\
(+05)\end{array}$ & $\begin{array}{r}\mathbf{- 5 . 7 1} \\
(+05)\end{array}$ & $\begin{array}{r}\mathbf{- 1 . 9 1} \\
(+05)\end{array}$ & $\begin{array}{r}\mathbf{- 5 . 1 2} \\
(+05)\end{array}$ & $\begin{array}{r}\mathbf{- 1 . 3 4} \\
(+05)\end{array}$ & $\begin{array}{r}\mathbf{6 . 1 4} \\
(+05)\end{array}$ & $\begin{array}{r}\mathbf{1 . 4 0} \\
(+05)\end{array}$ & $\begin{array}{r}\mathbf{3 . 7 5} \\
(+05)\end{array}$ & $\begin{array}{l}\mathbf{1 . 2 4} \\
(+05)\end{array}$ \\
\hline \multicolumn{13}{|l|}{ 3D FEA } \\
\hline$\varepsilon_{\mathrm{x}}$ & 14.1 & 2.60 & & & -5.70 & -1.91 & & & & & & \\
\hline$\varepsilon_{\mathrm{y}}$ & & 2.60 & 6.97 & & & -1.91 & -5.11 & & & & & \\
\hline$\gamma_{x y}$ & & & & - & & & & - & & & & \\
\hline$\kappa_{\mathrm{x}}$ & & & & & -5.73 & -1.91 & & & 6.15 & 1.40 & & \\
\hline$\kappa_{\mathrm{y}}$ & & & & & & -1.91 & -5.12 & & & 1.40 & 3.75 & \\
\hline$\kappa_{\mathrm{xy}}$ & & & & & & & & - & & & & - \\
\hline
\end{tabular}

Table 2. Comparisons of formulated stiffnesses to 3D FEA computed stiffnesses. (the reference plane is the facesheet midplane)

\begin{tabular}{|c|c|c|c|c|c|c|c|c|c|c|c|c|}
\hline CASE & $\mathrm{A}_{11}$ & $\mathrm{~A}_{12}$ & $\mathrm{~A}_{22}$ & $\mathrm{~A}_{33}$ & $\mathrm{~B}_{11}$ & $\mathrm{~B}_{12}$ & $\mathrm{~B}_{22}$ & $\mathrm{~B}_{33}$ & $\mathrm{D}_{11}$ & $\mathrm{D}_{12}$ & $\mathrm{D}_{22}$ & $\mathrm{D}_{33}$ \\
\hline $\begin{array}{l}\text { FORMU- } \\
\text { LATED }\end{array}$ & $\begin{array}{l}\mathbf{1 4 . 1} \\
(+05)\end{array}$ & $\begin{array}{l}\mathbf{2 . 6 0} \\
(+05)\end{array}$ & $\begin{array}{l}\mathbf{6 . 9 7} \\
(+05)\end{array}$ & $\begin{array}{r}\mathbf{2 . 1 2} \\
(+05)\end{array}$ & $\begin{array}{r}\mathbf{4 . 6 3} \\
(+05)\end{array}$ & $\begin{array}{r}\mathbf{0 . 0 0} \\
(00)\end{array}$ & $\begin{array}{r}\mathbf{0 . 0 2} \\
(00)\end{array}$ & $\begin{array}{l}\mathbf{1 . 2 8} \\
(+04)\end{array}$ & $\begin{array}{l}\mathbf{5 . 3 5} \\
(+05)\end{array}$ & $\begin{array}{l}\mathbf{5 . 4 1} \\
(+01)\end{array}$ & $\begin{array}{l}\mathbf{1 . 5 4} \\
(+02)\end{array}$ & $\begin{array}{l}\mathbf{1 . 5 9} \\
(+04)\end{array}$ \\
\hline \multicolumn{13}{|l|}{ 3D FEA } \\
\hline$\varepsilon_{\mathrm{x}}$ & 14.1 & 2.60 & & & 4.63 & 0.00 & & & & & & \\
\hline$\varepsilon_{\mathrm{y}}$ & & 2.60 & 6.97 & & & 0.02 & 0.00 & & & & & \\
\hline$\gamma_{x y}^{y}$ & & & & 2.12 & & & & 1.28 & & & & \\
\hline$\kappa_{\mathrm{x}}$ & & & & & 4.65 & 0.00 & & & 5.38 & 5.53 & & \\
\hline$\kappa_{\mathrm{y}}$ & & & & & & 0.00 & 0.02 & & & 5.43 & 1.54 & \\
\hline$\kappa_{x y}$ & & & & & & & & 1.29 & & & & 1.59 \\
\hline
\end{tabular}

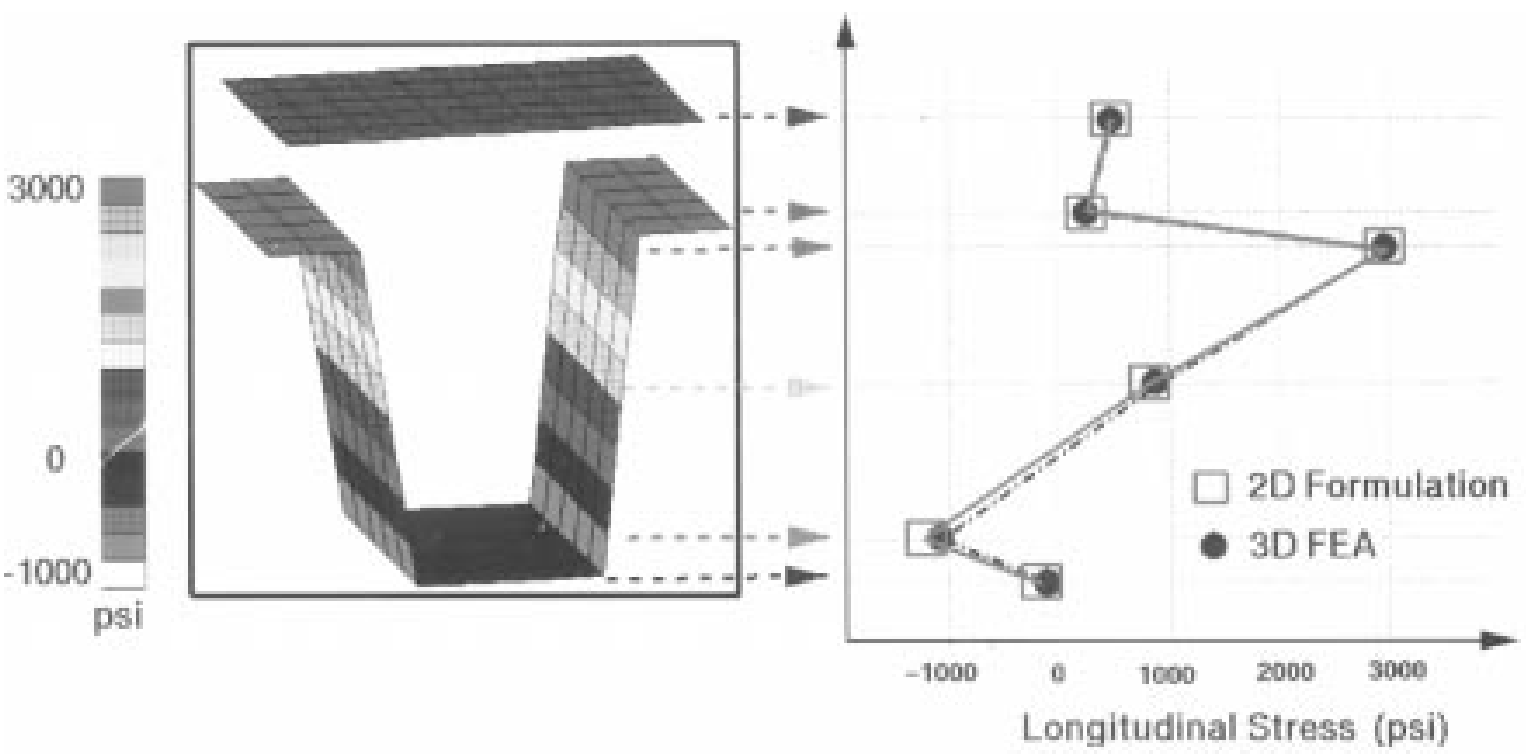

Fig. 6 Comparison of theoritical thermal residual stress to a 3D FEA solution. 